\title{
On the Names of States: Naming System of States Based on the Country Names and on the Public Law Components of State Titles
}

\author{
Peter Takács* (1D)
}

(Accepted 20 November 2019)

\begin{abstract}
General questions of name of the state are rarely discussed in the literature of public law, political science or legal theory, its terminology is neglected, and in its current state, it is a source of many misunderstandings. Pointed out these terminological problems this study proposes a theoretical framework for the naming system of states which takes into accounts the public law components of names. Among these components the significance of four factors are emphasized: the form of state (form of government), the structure, or organization of state, the role of seemingly neutral terms (for example, the words "commonwealth" or "state"), and, on the contrary, the role of politically, religiously or ethnically bound terms (such as "democratic", "people's", "Arab" or "Islamic") in the names of states. After clarifying the difference between the terms country name and state name (state title), this study shows that there are cases when the state name (state title) function as country name, and when the country name fulfills the communicative function of the state title.
\end{abstract}

Keywords: Legal aspects of the name of state; name of state and international law; state title and constitution; naming system of states regarding public law components of their names; geographical names; activities of UNGEGN; country name and name of state (state title)

\section{A. Introduction}

The issue of country name and state name, or in British English, often "state title," is rarely subject to analysis. This can be explained by the fact that the topic lies at the intersection of three disciplines: Linguistics, more specifically onomastics; geography, in particular, cartography; as well as political science, within that the theory of the state. It is, however, possible that this is not some kind of an intersection gaining the attention of several disciplines but a neglected no man's land that has received little scrutiny from all three fields.

This is well illustrated by the fact that the onomastics manuals tackle the issue only very briefly or not at all. ${ }^{1}$ Geographers deal with practical aspects of the issue; thus, they rarely formulate general theories. Political scientists, researchers of political institutions, and authors who grapple with theory of states (Staatslehre), including Staatslexikons and similar encyclopediæ, almost

\footnotetext{
${ }^{\star}$ Péter Takács is a professor of Jurisprudence and Theory of State at the Széchenyi István University in Győr, Hungary.

${ }^{1}$ See 1, 2 NAmEnforschung / NAME STUdies / LeS NOMS PROPRES (Ernst Eichler et al. eds., 1995). This manual has dealt with country names, but not with state names, in two short entries that make up 13 pages altogether of the 1800 page-long publication. See also id. vol. 2 at 1348-61; The OXFord HANDBOOK OF NAMES AND NAMING (Carole Hough ed., 2016). The Oxford Handbook of Names and Naming is a comprehensive, 771 page-long handbook which analyzes in detail all kinds of names; for example, personal and family names, the names of mountains, rivers, animals, ships, stars, and even planets, et cetera. But we are looking for the topic of country names and names of states in it in vain.
} 
always ignore the topic of the denomination of states. ${ }^{2}$ The only exception is comparative constitutional law, where recently, a detailed encyclopedia entry was published to fill the gaps in the legal and constitutional analysis concerning the names of states. ${ }^{3}$

One of the consequences of this neglect is that there is no lively general literature developed on this theme, although there are some thorough analyses on the names of particular states - peculiarly on that of the states of the United States of America-and on the name debates between states, such as concerning the names of Macedonia and Taiwan, or debates concerning names inside a single country, for example, Czechia. For this reason, the relevant terminology is far from being uniform and contains much uncertainty.

\section{B. Name of the State: What Is It and Why Does It Matter?}

States, like all unique beings, have specific names. As individual human beings might have more than one name-usually first and last ones which are termed, according to the ideas established in different cultures, forename, personal name, given name, Christian name, family name, and surname, not to mention the middle name, second name, maiden name, nickname, and different kinds of pseudonyms such as nom de plume, sobriquet or moniker-states can have more than one name too at the same time. According to the current practice of the naming system of states in formal communication, we can denominate particular states by two separate names-the few exceptions I will mention below. Beyond these, in informal communication, even states can be designated by nicknames, ${ }^{4}$ habitually accepted names, ${ }^{5}$ informal abbreviation ${ }^{6}$ or sobriquet. ${ }^{7}$ This study focuses primarily on names used in formal communication and examines the system in which the two common formal names are utilized.

The current practice of the naming system of states dates back about a century. It was not introduced by a considered institutional decision, but evolved over decades through piecemeal engineering without a definite plan or design. The system itself is based on implicit conventions that are maintained by the customary forms of internal and international communication.

Of course, states had names well before the 20th century. The practice of denominating them was diverse and disorganized, however. Certain states often did not have the exact names by which they could be identified or had only habitually accepted names, which could be used with approximate accuracy. It is often said, for example, that up to 1804 the Habsburg monarchy was an umbrella term for a political entity which had no official name, whatever the term "official name" means here. During the 18th century, this political entity was slowly called by the adjective Austrian, comprising all Habsburg dominions. ${ }^{8}$ After that, from 1526 to 1867, this state was called, both retrospectively and going forward, Monarchia Austriaca, which had two other names for its

\footnotetext{
${ }^{2}$ There is no entry on the name of state (Staatsname) in the standard lexicons of theory of state. See, e.g., 1-7 StaAtslexikon (Heinrich Oberreuter ed., 2017); Evangelisches StaAtslexikon (Werner Heun et al. eds., 2006).

${ }^{3}$ See Manuel Brunner, Name of a State, in MaX Planck EnCyClopedia of Comparative Constitutional LaW \$\$ 1-34 (Rainer Grote et al. eds., 2018).

${ }^{4}$ See, especially, the nicknames of the member states of the United States; for example, The Golden State, Silver State, Empire State, et cetera.

${ }^{5}$ Such as "Britain" instead of "Great Britain" as a sovereign state from 1707 to 1801.

${ }^{6}$ For example, "the States" instead of "the United States," mainly in personal conversation.

${ }^{7}$ For example, "Murica” for the United States in certain social contexts.

${ }^{8}$ See Michael Hochedlinger, Austria's Wars of Emergence, 1683-1797 9 (2d ed. 2013) (“Around 1700-after the reconquest of Hungary, which raised the Habsburg conglomerate to full great-power status-the term monarchia austriaca was coined, which embraced all Habsburg dominions ... From 1740 on ... we should use the 'Austrian' or 'Habsburg' as appropriate adjectives."). This development was also reflected by artwork representing political processes. The ceiling fresco of the Italian painter Gregorio Guglielmi, entitled the "Glorification of the Monarchia Austriaca" (1760), still in the Schönbrunn Palace today, focuses on Maria Theresa, sovereign of the Archduchy of Austria, the major principality of the Holy Roman Empire, and her husband, Francis I, the emperor of the Holy Roman Empire. Around them are the allegorical representations of the most important Crown Lands of the monarchy.
} 
later periods: From 1804, its transformed form was called the Austrian Empire (German: Kaisertum Österreich), whereas its successor state was denominated Austro-Hungarian Monarchy from 1867 to 1918. Informally, all three were named Danubian Monarchy (German: Donaumonarchie), and the last one Dual Monarchy (German: Doppel-Monarchie). At the early stage in the development of modern states, this linguistic contingency has not caused any unsolvable problems in the real processes of politics or in legal matters, because actually those terms were used both in internal and international communication to refer to states, most of them still monarchical, which were derived from the earlier forms of personal domination and traditional institutions.

Another example shows, however, that linguistic uncertainty could lead to palpable problems if it obscured reality. This was the case with the so-called German-Roman Empire, which was, in varying constellations of territories and personalities in its long history, referred to by different names: Originally by Imperium Romanum; subsequently, after 1157, by Sacrum Imperium in the sense of being consecrated; and finally after 1512 by Sacrum Imperium Romanum Nationis Germanicae. By the 18th century its name had become deceptive, leading Voltaire to sarcastically remark in 1756: "This agglomeration which was called and which still calls itself the Holy Roman Empire was neither holy, nor Roman, nor an empire."

During the 19th century, the need for linguistic clarity had become increasingly widespread due to the fact that international relations had intensified. New forms of diplomacy emerged, many new independent states were created, and peace conferences, political alliances, and other collaborations created organizations with more or less permanency. All these factors pointed to the emergence of a unified new system with regard to the functions of names. The name of the state may perform different functions in communication in states and between states: It identifies a phenomenon, points out or denotes it if necessary, and sometimes describes some of its features. By using names, people or other states invoke or address a state and its representative organ, whereas the states themselves may remember their own history, and it is not uncommon that they supply or withdraw information in relation to their names. Names of states are used to represent an established institution or organization, and for legitimization of a new social, political, and legal order as well. They are useful for identity-creation and identity-protection of a political community. This variety of features required a new naming system, with the use of names being more important than ever. Throughout the 20th century, a new practice emerged in which states can be, and should be, named by one of their two names: Either by country name or by state titles. These kinds of names, their practical use, and their exceptions will be detailed below. This practice was strengthened and essentially completed by the formation of the United Nations (UN) and subsequent activities of its specialized agencies which I will also discuss later in detail.

The main question in this Article is whether the formal names actually used by states fit into a broader system and if so, what are the main elements and rules of that system, if any. As the designation of states is important in both international and internal communication, this Article will examine the question of whether it is regulated by any sort of law.

\section{International Law and the Names of States}

Concern about naming a state arises when a new state emerges or a state undergoes a major transformation and changes its name. In this regard, James Crawford's theory can be taken as a starting point to evaluate the role of international law in naming states. In his book on the creation of states in international law, James Crawford argues that at the time of the creation of individual states,

\footnotetext{
${ }^{9}$ See 7 CEUVRES COMPLÈTES DE VOLTAIRE: ESSAI SUR LES MOEURS ET L'ESPRIT DES NATIONS, ET SUR LES PRINCIPAUX FAITS DE L'HISTORIE, DEPUIS CHARLEMAGNE JUSQU'A LOUIS XIII 416 (1859). It is worth noting that this witty Frenchman, who otherwise used a nom de plume (pen name) and not his real one, did not mention the fourth element of the name of the neighboring realm, namely, Nationis Germanicoe.
} 
disputes over the names of new states are possible but international law does not have any provision as to the choice of state names. ${ }^{10}$ The same applies to the subsequent existence of states: International law does not have any regulation as to the rights and duties of states regarding their names. The fact that states are expected to notify any changes in their names to the other states at the United Nations - inasmuch as they are in connection to the UN or any of its specialized agencies, which is the case for almost every state today-and that the rules and procedures of this notification are established by some office, department, or division of the UN does not mean that international law has binding rules on the choice of state names. Any rules on the notification of changes in the name of a state-which unit should be informed, how, and so on-are only internal organizational rules and not legal in their character, and there is no legal consequence of noncompliance with them by a state. For instance, Swaziland changed its name to Eswatini, which means the land of Swazi, or Swati, in Swazi, in May 2018. The ruler of the country, King Mswati III, however, has been using the new name since 2014 both in domestic and international communication, including his speech at the UN General Assembly. ${ }^{11}$

The fact that public international law does not impose duties or provide rights regarding the determination of the names of individual states does not mean that solutions for the name disputes between states cannot be fostered by the tools of international law. The best-known case in this regard is the Greek-Macedonian conflict evolving over the name Macedonia, whereby Greece had been hindering the international integration of its new neighbor for twenty-eight years. In order to solve this dispute, international legal tools-including the involvement of the United Nations ${ }^{12}$ and the International Court of Justice ${ }^{13}$ - were resorted to. Nevertheless, the solution for the dispute was reached in 2019 through a bilateral accord. ${ }^{14}$ After this name debate had been settled, and having observed the ways of its solution, we may say that there are no general rules for state names in international law, but individual states can agree on specific rules.

In line with new developments, private international law confers protection on certain aspects of geographical names related to commercial interests. Due to the fact that the names of states or country names often became part of domain names in abbreviated forms, some scholars believe that considerations regarding the security of domain names can be extended to the names of states as well. ${ }^{15}$ This, however, cannot be taken as self-evident; in fact, this is a rather disputable statement, because domain names and state names are quite different things and they are subject to different kinds of legal rules.

Although there are no general legal rules for state names in international law, many other factors can influence the behavior of individual states in diplomacy and within other frameworks of

\footnotetext{
${ }^{10}$ James R. Crawford, The Creation of States in International LaW 67-68, 204, 296, 308 (2d ed. 2006).

${ }^{11}$ See His Majesty King Mswati III, Head of State of the Kingdom of Swaz., Statement on the Occasion of the General Debate of the $72 \mathrm{~d}$ Session of the United Nations General Assembly (Sept. 20, 2017), https://gadebate.un.org/sites/default/files/ gastatements/72/sz_en.pdf; His Majesty King Mswati III, Head of State of the Kingdom of Swaz., The Opening Speech of the Parliament of the Kingdom of Eswatini (2014), http://www.gov.sz/images/speech\%20from\%20the\%20throne\%202014.pdf.

${ }^{12}$ The Interim Accord Between the Hellenic Republic and the Former Yugoslav Republic of Macedonia, Sept. 13, 1995, 1891 U.N.T.S. 3, http://www.hri.org/docs/fyrom/95-27866.html.

${ }^{13}$ Application of the Interim Accord of 13 September 1995 (the former Yugoslav Republic of Maced. v. Greece), Judgment, 2011 I.C.J. 644-94 (Dec. 5).

${ }^{14}$ See S.C. Res. 817 (Apr. 7, 1993); S.C. Res. 845 (Apr. 7, 1993) (describing the Final Agreement for the Settlement of the Differences); Final Agreement for the Settlement of the Differences as Described in the United Nations Security Council Resolutions 817 (1993) and 845 (1993), The Termination of the Interim Accord of 1995, and the Establishment of a Strategic Partnership between the Parties, Maced.-Greece, June 7, 2018, htps://www.un.org/pga/73/wp-content/uploads/ sites/53/2019/02/14-February-Letter-dated-14-February-2019.pdf. See also Dimitrios Dimitrakos, Greece's Ratification Procedure of the Final Settlement Agreement between Greece and FYROM, 22 ASIL INSIGHTS (2018), https://www.asil.org/ insights/volume/22/issue/18/greeces-ratification-procedure-final-settlement-agreement-between.

${ }^{15}$ See generally The Protection of County Names in the Domain Name System, Standing Committee on the Law of Trademarks, Industrial Designs and Geographical Indications, WIPO Doc. SCT/S2/INF/5 (May 14, 2002); HEATHER ANN Forrest, Protection of Geographic Names in International Law and Domain Name System (2d ed. 2017).
} 
international relations concerning the usage of names, the same way as the use of flags and coats of arms. For example, states usually act in line with the requirements of international comity in their relations with one another. This common practice was utilized by Côte d'Ivoire, an independent state since 1960, when in 1986, it tried to prevent the negative associations triggered by its name, which had originally been given by the French. Indeed, even in the 20th century, this name reminded many of the least praiseworthy economic endeavor of colonial times- the ivory export. The government attempted to solve this issue by declaring that it does not endorse the translation of the state name into different languages and requests the retention of the original French name. ${ }^{16}$ A well-known example for the power of rules of comity is provided by the fact that in the framework of diplomatic relations of states once falling under the sphere of influence of the former Soviet Union, it is inappropriate to call Sakartvelo (bsfınозэмm; in English, Georgia), located in the Caucasus region of Eurasia, "Grusia" (z(nylos), a name that, for many, recalls the memories of Russian-Soviet influence.

The fact that international law does not regulate the issue of the name of states-namely, that until now states have, in principle, kept the authority to determine their names ${ }^{17}$ - has several consequences. Most importantly, it is not possible to talk about an official state title or name in this regard because the meaning of "official" cannot be determined precisely. For the time being, officialness only makes sense within states or in the context of the purview of states. Consequently, official state names could be different in the internal legal system of each state even though this extreme situation never occurs in practice. It is possible, however, and often happens, that a state is named and addressed by different official names in different countries. For instance, the State Department of the United States of America has retained the use of Burma in the case of Myanmar even after it—although not by acknowledged constitutional means-changed its name decades ago. ${ }^{18}$ According to the list of the United Kingdom, Myanmar's country name is "Myanmar (Burma)" while its state name or official state title is the Republic of the Union of Myanmar. ${ }^{19}$ According to the German list of state names, the country's name is Myanmar and the complete name of the state is Republik der Union Myanmar emphasizing that "Birma' und 'Burma' sind im Deutschen gebräuchlich" ("In German 'Birma' and 'Burma' are [also] common”). ${ }^{20}$

\section{Constitutions and the Names of States}

In internal affairs, denomination of states is often a matter of constitutions. We should note, however, that constitutions-except where state name was changed by the constitution itself, a question I will return to later-do not very often determine the name of the state directly. They do so, if at all, at most indirectly. Getting to know both names of a state by reading its constitution is an exception rather than the rule.

Of course, we can find clear determinations of names of states by constitutions. Examples may be the constitution of Andorra and the basic laws of Israel. According to the former,

\footnotetext{
${ }^{16}$ Therefore, the term Ivory Coast in the state name stands only in French — at least in the major linguistic cultures of global communication (English: Republic of Côte d'Ivoire; Spanish: República de Côte d'Ivoire (la); Russian: Республика Кот-д’Ивуар; Chinese: 科特迪瓦共和国; Arabic: جُمْهُورِيَّة كوت ديفو إر). The goal of the Government of Côte d'Ivoire would have been reached only if the majority of participants of global communication failed to understand the French terms or made only France responsible for what has happened before the 20th century. Both assumptions were fairly naïve.

${ }^{17}$ See Ilias Bantekas, The Authority of States to Use Names in International Law and the Macedonian Affair: Unilateral Entitlements, Historic Title, and Trademark Analogies, 22 LEIDEN J. INT'L L. 563-82 (2009).

${ }^{18}$ See U.S. Dep't of STAte, Countries \& AREAS, https://www.state.gov/countries-areas/ (last visited July 11, 2020).

${ }^{19} \mathrm{See}$ The Permanent Committee on Geographical Names for British Official Use, Country names, https://www. gov.uk/government/publications/country-names/country-names-the-permanent-committee-on-geographical-names-forbritish-official-use (last visited July 26, 2020) [hereinafter COUNTRY NAMES].

${ }^{20}$ See StÄNDiger Ausschuss FÜr GEOGRAPHISCHE NAMEN [STAGN], Liste DER STAATENNAMEN UND IHRER ABLEITUNGEN IM DeUTSCHEN 10 (2014), https://www.stagn.de/SharedDocs/Downloads/DE/StAGN_Publikationen/140408_STAATEN NAMEN_13_ol.pdf?_blob=publicationFile\&v=4 [hereinafter LISTE DER STAATENNAMEN].
} 
"Sa dénomination officielle est Principat d'Andorra;" in essence, "Its official name is Principat d'Andorra (Principality of Andorra)." ${ }^{21}$ According to the latter, "שמה של המדינה הוא ישראל;" in essence, "the name of the state is 'Israel." 22 But constitutions do not always contain such palpable or specifically worded provisions.

Indirectly, constitutions or basic laws of similar status generally mention at least one of the names of the state; for instance, in their titles. An example is provided by the 2015 Constitution of the Dominican Republic, an independent state since 1844, as well as the 1978 Constitution of the Commonwealth of Dominica, independent since 1978. The former, which is the state's 39th constitution, not only contains the name of the state in its title but also designates it in Article 1, while the latter, which does not denominate the state in a separate provision, only refers to the name of the country. ${ }^{23}$

When the name of the state cannot be determined on the basis of the title of the constitution, it is possible to do so through the determination of the form of state even though there are reticent, shy, and illusive, or even delusive constitutions in this regard whereby knowledge of form of state, or form of government, does not enable the denomination of the state. The 1978 Constitution of Spain, for instance, can be regarded a reticent constitution whose text contains the terms "Spanish State" and "parliamentary monarchy," but it—due to historical reasons dating back to pre-1978 times ${ }^{24}$ _does not call Spain Kingdom of Spain (in Spanish: Reino de España) even though everyone is aware of the fact that this is one of the names of the Spanish state.

The Fundamental Law of Hungary has changed the name of the Hungarian state from the Republic of Hungary to Hungary, effective since 2012. After the change, the name Republic of Hungary had been erased from hundreds of legislations, and so too had the names of thousands of public administrative bodies, courts, and other authorities changed, losing the word republic. Until 2012, the judgments of courts were pronounced "in the name of the Republic of Hungary"; after 2012, this introductory part of the judgments was dropped. The reasons for change had been debated for years during the 2010s, but by now it has probably become obvious: The weakening of the republican vocabulary in public life, which confirmed the newly built political regime through everyday language usages. Such an objective is called a legitimizing purpose, even in the case when it has furthered some policy which was not made public or obvious. Those who think that the founders of the constitution did not clarify the real reasons for renaming the state ${ }^{25}$ will qualify this change as making the constitution reticent, whereas those who assume that they intentionally have not declared these reasons straightforwardly because of the information retention concerning the political circumstances behind the alteration will call this change delusive in its nature. ${ }^{26}$

\footnotetext{
${ }^{21}$ CONST. OF THE Principality of ANDORRa, art. $1, \S 1$.

${ }^{22}$ National Basic LAW of IsRael, art. 2(a).

${ }^{23}$ See CONST. OF THE Dom. ReP., art. 1 ("[T] State, named the Dominican Republic."); CONST. of THE Commonwealth of DominicA, art. 116 ("Dominica shall be a sovereign democratic republic."). The name "Dominica" in this latter example can be classified as country name in a position of state name.

${ }^{24}$ Spain as a state called herself "Spanish State" (in Spanish: Estado Español) between 1936 and 1947, "Kingdom of Spain" (in Spanish: Reino de España) between 1947 and 1975, and again "Spanish State" between 1975 and 1978.

${ }^{25}$ See The Fundamental Law of Hungary, art. A ("The name of our country shall be Hungary.") (official translation). In fact, the accurate English translation of the clause that is understood as renaming the State would be the following: "The name of our homeland shall be Hungary." The Hungarian text is as follows: "Hazánk neve Magyarország." If the latter translation is correct, as I claim, we will only get to know explicitly from the justification of the Fundamental Law that the name referring to the "homeland" also applies to the state; therefore, the denomination of the "Republic of Hungary" could not be used as state title. I discuss this issue in a separate study. See Peter Takács, Renaming States-A Case Study: Changing the Name of the Hungarian State in 2011. Its Background, Reasons, and Aftermath, INT'L J. SEMIOTICS L. (2020), https://link.springer.com/ article/10.1007/s11196-020-09692-y.

${ }^{26}$ This statement is reinforced by the fact that on the basis of its country name, namely by the short-form of state name, the Hungarian state could have been called "Hungary" in any context even before 2011. Thus, the Fundamental Law of Hungary,
} 
The opposite of the retention or withdrawal of, or reticence about, information occurs when a constitution is too talkative or garrulous: It uses both the country name and state title or employs state names of different kinds alternatively. This applies, for example, to the Constitution of Italy, which refers to the Italian state by using three different names: In some articles it is called $\mathrm{La}$ Repubblica (Republic); in other places it is called Stato (state); and again, in some other places Italia (Italy). ${ }^{27}$

It is partly because of the reticent-or, on the contrary, talkative-nature of individual constitutions that the constitutional name of state (state name determined by the constitution) is not a widespread terminological category. Nevertheless, there are occasions when it is impossible not to use this term, and even when it can be strongly recommended to use it. As an example for the first case, see the above-mentioned judgment of December 5, 2011 of the International Court of Justice concerning the dispute between Macedonia and Greece in which the court resorted to the constitutional name thirty-seven times. ${ }^{28}$ An example for the second case might be the constitutional analysis of state names, in which names of states are obviously examined from the point of view of constitutions. ${ }^{29}$

Constitutions of federal states have different attitudes toward the name of their member states. There are some that only enumerate their member states without ruling out or regulating the issue of the name change. According to the 1920 Constitution of Austria, amended in 1929, the "Federal State" constitutes nine independent member states which are specifically called by their names and enumerated in the constitution. "The Federal State is constituted by independent Länder: Burgenland, Carinthia, Lower Austria, Upper Austria, Salzburg, Styria, Tirol, Vorarlberg and Vienna." ${ }^{30}$ It has, however, not even mentioned whether these names were possible to change and if they are, then how. The 1949 Basic Law of Bundesrepublik Deutschland (then West Germany or the German Federal Republic in some languages, now the Federal Republic of Germany universally) offered a similar solution inasmuch as it referred to member states or Länder by their country names (Landnamen) in its Preamble, without mentioning their highly diverse long state names and while subsequently remaining silent on the possible change of their names.

In contrast, according to Articles 3 and 4 of the Constitution of India, the Federal Constitution shall determine the name of member states or shall regulate the process of changing them. This constitution even enables the change of the name of a member state without a constitutional amendment in normal legislation. ${ }^{31}$ Due to this regulation, the names of eight member states out of twenty-nine have been changed since the time India became an independent state in $1947 .^{32}$ Nonetheless, the last effort for changing the name of a member state was not successful. The government of West Bengal (পশ্চমিবঙ্গ) had wanted to change its name to Bengal (which is Bangla (বাংলা) in Bengali) since 2011, and this was decided by the Legislative Assembly of West Bengal in 2016, but it was not supported by the political forces on the federal level. The reason for

2011 did not, in fact, "rename" the state but made the use of the name "Republic of Hungary" impossible or at least significantly restrained.

${ }^{27}$ See, e.g., Arts. 5, 6, 12 Costituzione [Cost.] (It.) (referencing the first mentioned denomination: Republic); Arts. 7, 8, 28 Costituzione [Cost.] (It.) (referencing the second mentioned denomination: State); Art. 11 Costituzione [Cost.] (It.) (referencing the third mentioned denomination: Italy). The word "Italy" in Article 1 can be classified as "country name." In Article 11 , the "country name" is used in the position of state name.

${ }^{28}$ See the former Yugoslav Republic of Maced. v. Greece, 2011 I.C.J. at 644-94.

${ }^{29}$ See Brunner, supra note 3 , at 25-28.

${ }^{30}$ Bundes-Verfassungsgesetz [B-VG] [CONSTitution] BGBL No. 1/1930, as amended by Bundesverfassungsgesetz [BVG] BGBL I No. 153/2004 (Dec. 30, 2004) art. 2, \$2.

${ }^{31}$ See INDIA CONST. art. 368.

${ }^{32}$ The name of East Punjab has been changed to Punjab; the United Provinces to Uttar Pradesh; Hyderabad to Andhra Pradesh; Travancore-Cochin (or Thiru-Kochi) to Kerala; Madhya Bharat to Madhya Pradesh; Madras to Tamil Nadu; Uttaranchal to Uttarakhand; and Orissa to Odisha. 
the lack of support was that "Bangla" would have been very similar to the name of the neighboring country, Bangladesh (বাংলাদশে). So, in this case, the name of the member state was not changed.

Claiming that the constitutional name is not a widespread category for the analysis of denomination of states does not mean that constitutions should have nothing to do with the state names. For example, constitutions, apart from directly or indirectly determining the name of the state, may designate the constitutional organ that can decide on a new name for a state, such as the 1987 constitution of the Philippines does, or provide for the protection of the proper form of state title in a multilingual country, as exemplified by the constitution of Papua New Guinea. ${ }^{33}$

\section{The Terminology of the Denomination of States}

An analysis of the naming system of states requires categories with clear meaning. This applies also in the sense that the two names of states should be denominated with semantically matching terms, in a coherent terminology. As we will see, this is not always the case. The types of state names - in essence, the "names of names"-show, on the one hand, conceptual overlapping and, on the other hand, terminological divergence.

\section{Examples of Terminological Difficulties in Denominating States}

While some terminological systems, including the German one, differentiate between short and complete forms (German: Kurzform and Vollform) of the state name, others, like the British, distinguish between country names and official state titles. The example below illustrates substantial contradictions caused by this terminology.

In German usage, the short-form of state name is not contrasted with the long or official, but with the complete form. ${ }^{34}$ Thus, while France is paired with the French Republic, the short name of Jordan (الأرْدُنّ, al-'Urdunn) is not matched with a similar long-form such as the Kingdom of Jordan, but the actually existing Hashemite Kingdom of Jordan (المكلكة الأردنية الهانثية), al-Mamlakah al-Urduniyah al-Hāshimiyah). The same way, Laos (6มอิอวาอ) is not matched with the non-existent Republic of Laos but the actually existing Lao People's Democratic Republic (ราชาวะบะลัล บะฉาทีบะไต บะฉาวิบวาอ, Sathalanalat Paxathipatai Paxaxon Lao).

The long and the official forms of names do not have the exact same quality as the complete form, given the fact that the latter contains the long-form and, in many cases, something else: Some kind of a political classification, religious commitment, or ethnic denotation; for example, a reference to the "people's" republic, commitment to Islam, or an expression of "Arab" quality. What's wrong with that? For nearly three decades, between 1991 and 2019, the now obsolete dual state name of the new Macedonia-the Republic of Macedonia (Република Македонија) and the Former Yugoslav Republic of Macedonia (Поранешна Југословенска Република Македонија, abbreviated FYR Macedonia or FYROM) — had well demonstrated the difference between the long and official forms of state name. Because the country name Macedonia, in principle, could have been well used as a state name, this new state really had three names. Nevertheless, many opined that there was something wrong with them. ${ }^{35} \mathrm{~A}$ further frequent example for such anomalies is the two complete names of the Vatican, namely Vatican City State and Holy See (German: Vatikanstadt and der Heilige Stuhl). The former is used in a descriptive sense, denominating the state, while the latter is employed in a vocative meaning, for example, in diplomatic relations,

\footnotetext{
${ }^{33}$ See, e.g., CONST. (1987), art. XVI, $\$ 1$ (Phil.) ("The Congress may, by law, adopt a new name for the country ... Such law shall take effect only upon its ratification by the people in a national referendum."); CONST. OF THE INDEP. STATE OF PAPUA N.G., art. 1, $\$ 2$ (Part I, Div. 1) ("The name of the Independent State of Papua New Guinea and its variants shall be protected by an Act of the Parliament."). Both examples are in Brunner, supra note 3, at 27-28.

${ }^{34}$ LisTe DER STAATENNAMEN, supra note 20 , at 1.

${ }^{35}$ For an objective summary of the cause, main reasons, and the course of this name debate, see Brunner, supra note 3 , at 16-21. For a detailed literature of the "Macedonia" name debate, see Bantekas, supra note 17; infra notes 47-48.
} 
recognizing, or at least respecting the underlying theological, canonical, and political theoretical (staatstheoretische) aspects.

The British usage-which employs the terms "country name" and "official state title" instead of short and complete names - suggests that, in contrast to the official state title, the country name is not, or not necessarily, an official name. ${ }^{36}$ The authors of the List of Country Names by the Permanent Committee on Geographical Names for British Official Use correctly remarked that while the former - the country name-usually reflects the current British usage, the latterthe official state title-is intended for use by all government departments of the United Kingdom. The use of official names in documents and texts other than those of the government departments of the United Kingdom, such as scientific analyses, however, could lead to confusion inasmuch as both names can be official within particular states, and none can be official in universal, inter- or supra-state senses. This is because there is no supra-state forum that could establish the general criteria for officialness covering all countries or at least the majority of them. Although the documents of the United Nations, especially those of the Secretariat, contain various sources whereby the names of states, even allegedly official ones, can be found, "[t]here ... exists no single widely accepted list of country names." ${ }^{37}$ Special recognition of this fact is found on the website of a UN panel of experts - to which I will return later-when it lists the recommended and not official country names. The background to this matter is that international law seems to be permissive and compliant concerning the names of states.

\section{Further Examples of the Terminological Disorder}

Lists contrasting the short name of states not with their complete or full names but with their official name are, in some of the above examples, bound to allow for explicit exceptions, either at the level of short or official names. Although there are several possible examples, I refer here to the list of states that is in official use in Poland. Its supplementary text argues as follows: "It is recommended to use one short name and one official name for the same country. An exception was made for Macedonia and Vatican City, for which two full names have been established, as suggested by the Ministry of Foreign Affairs." Thus, according to the Polish practice, these states, in fact, will have three names. "Furthermore, variant short names have been recommended for two countries: Mjanma and Birma [English: Myanmar, Burma]; Wielka Brytania and Zjednoczone Królestwo [English: Great Britain, United Kingdom]." ${ }^{38}$ The latter examples transfer the distinction between the official or legally accurate and socially widespread variants of proper nouns, based on actual language usage, to the names of states. That being said, as long as everyone is aware of the distinction between formal-legal and social-sociological usage of names in the context of proper nouns-for example, if Margaret or Maggie is used when talking about Margaret Thatcher-in the case of states no reference can be made to establish this distinction. So as long as there is no supra-national law regulating the conditions of the usage of the names of state that could function as a point of reference in this regard, there is no reason, or at least no basis, for differentiating between legal and social usage of state names, beyond the conventional rules and customs. Problems such as those existing in the List of Polish Names of Countries, and in several other national lists, can only be avoided by combining terms of different kinds.

This combination of terms or merging them into one terminological body, however, will lead to another sort of problem, as we can see in many documents of the United Nations Group of Experts

\footnotetext{
${ }^{36}$ See COUNTRY NAMES, supra note 19 , at 1.

${ }^{37}$ Michael, A. Froomkin, When We Say US ${ }^{\text {ma }}$, We Mean It!, 41 Hous. L. REv. 839, 846 (2004) (quoting Status of Country Names in the.info Top-Level Domain, Standing Committee on the Law of Trademarks, Industrial Designs and Geographical Indications, WIPO Doc. SCT/S2/4, at 4 (Mar. 29, 2002)).

${ }^{38}$ Comm'n on Standardization of Geographical Names Outside the Republic of Pol., Official List of Names of COUNTRIES AND NON-SELF-GOVERNING TERRITORIES VIII (2017) (emphasis added).
} 
on Geographical Names (UNGEGN). ${ }^{39}$ One of them refers to "the short, as well as the full or formal, names of States Members of the United Nations"40 concerning the standardization of geographical names, and as such, state names. Because a short name of a state, namely the country name, might be seen in many respects and in many procedures formal as well, the full and formal names should not be regarded as each other's alternatives or pairs.

Some scholars have tried to standardize the terms of geographical names, to that of country names, within the institutional framework of UNGEGN. Until now these endeavors were not successful as far as the issue of the name of the state is concerned. The reason for it was, in my view, that they had circumvented the terms of name of state, state title, or state name in the terminology. It is perplexing to read in UN documents mentioning the "UN Member States" several times that they do not call these states "states" when they speak of their names. For example, in the terminological list known as UNGEGN Glossary and in its addendum, ${ }^{41}$ the standardization of terms in case of country name and state name is done by the authors and the editor, first referring to full title as long-form of name," followed by defining long-form of a name, so that it might refer to any and many geographical names. Thus, as the example of the Glossary shows, it can also take the form of a "complete form of a toponym," "in particular the name of a country." ${ }^{2}$ So this document, and later its national variants ${ }^{43}$ as well, has been worded in such a way that their authors would not have to face the differences between, and the intricate relationship of, country and state and consequently country name and state name. In doing so, as it will become clear later on, they inevitably should have to deal with sensitive political and public law issues, and in fact, they wanted to avoid that. It is informative, and in a sense a bit annoying, to realize that escaping from political and public law issues can be a motive for building up a huge body of bureaucratic knowledge of terminology, the value of which might well be illustrated by the fact that it never corresponds entirely to reality. This terminology, while it will never be finished, must always be improved.

Despite this criticism, it is to be appreciated positively on this point that this Glossary is the only document-as opposed to the language usages observed by the German, British, Polish, Hungarian, many other national name authorities, Ständige Ausschüsse, permanent committees, and the like-that consistently maintains a close linkage between the short and the long form of names, considering them as complementary terms. The only problem is that this terminology is applied neither by national name authorities nor - weirdly enough - by the UNGEGN itself. We see this if we compare, for example, the Lists of Country Names submitted for the 2002 and 2019 Conferences of UNGEGN. ${ }^{44}$ The former considered complementary the terms of the short

\footnotetext{
${ }^{39}$ This is one of the expert groups of the Economic and Social Council (ECOSOC). It was formed and started its activity as an ad hoc group in 1967 and was formalized after its second conference in 1972. It is acting in working groups that are coordinated and administratively assisted by an office. Presently it has nine working groups - the theme of the name of state falls primarily on the field of the activities of the Working Group on Country Names.

${ }^{40}$ See U.N. Grp. of Experts on Geographical Names, Manual for the National Standardization of Geographical Names, at 91, U.N. Doc ST/ESA/STAT/SER.M/88 (2006) (emphasis added).

${ }^{41}$ See U.N. Grp. of Experts on Geographical Names, Glossary of Terms for the Standardization of Geographical Names, U.N. Doc ST/ESA/STAT/SER.M/85 (2002), http://unstats.un.org/unsd/geoinfo/UNGEGN/docs/glossary.pdf. For its addendum, visit https://unstats.un.org/unsd/geoinfo/UNGEGN/docs/pubs/glossary_add_e.pdf.

${ }^{42} I d$. at 16 .

${ }^{43}$ For the German version of this Glossary, see German Glossary of TOPONymic Terminology (Peter Jordan \& Bernd Beinstein eds., 3d ed., twenty-sixth UNGEGN session, Vienna 2011). For the Polish version, see SŁOWNIK TERMINÓW UŻYWANYCH PRZY STANDARYZACJI NAZW GEOGRAFICZNYCH (Warszawa, Główny Urząd Geodezji i Kartografii eds., Marek Łukasik trans., 2014). For the Hungarian version see, Magyar változat, A földrajzi nevek egységesítése során használt terminusok jegyzéke [Glossary of Terms for the Standardization of Geographical Names (Hungarian Edition)], in MAGYAR ÉS NEMZETKÖZI NÉVTANI TERMINOLÓGIA [Hungarian and International Onomastic Terminology] (Andrea Bölcskei, Tamás Farkas \& Mariann Slíz eds., Uppsala \& Budapest, International Council of Onomastic Sciences \& Magyar Nyelvtudományi Társaság, 2017) at 125-176.

${ }^{44}$ See Eighth U.N. Conference on the Standardization of Geographical Names, List of Country Names Submitted by the United Nations Group of Experts on Geographical Names, U.N. Doc. E/CONF.94/CRP.11 (May 31, 2002), https://unstats. un.org/UNSD/geoinfo/UNGEGN/docs/8th-uncsgn-docs/crp/8th_UNCSGN_econf.94_crp.11.pdf; U.N. Group of Experts
} 
or standard and long or full, expanded, and official names, whereas the latter considered complementary the short and formal ones. ${ }^{45}$ If we take this seriously, the conviction that all efforts of making the UNGEGN Glossary, its addendum, and its national versions were completely redundant is inevitable.

\section{Country Names and State Names}

The strongest interrelations and most serious discrepancies occur between the matched country name and state name. These two terms are generally used as synonyms; however, confusion is caused by their semantic difference, or difference in meaning, that particular national lists of states attempt to solve by employing more than one category, but which-inasmuch as they merge the above terms - they fail to remedy.

The substantial interrelation between these two terms used for the denomination of states is simple: Country names are often used to denominate states at the same time. Yet the interrelation is not completely valid: The names of particular states do not necessarily refer to countries that actually exist. Although perhaps due to various reasons, most often this is caused by political divisions within the country, or the situation of one divided country - two states. The historical example of Germany is well-known. ${ }^{46}$ The current situations in Congo and Korea mirror the German example. In such cases, the reference to an orientation - for instance, West Germany, East Germany, North Korea, South Korea-or the employment of some additional criterion, for example, the republican or democratic character of a state such as in the case of Congo, serve as solutions to the practical problems of denomination. In theory, however, the question arises whether these two territories and the peoples living there can be regarded as the country of these states in perpetuity.

The reverse of this situation offers a significant addition to this matter: Country names supplemented with reference to geographical directions do not always mean that the thus distinguished two territories constitute a single country and that they belong together. A characteristic example is provided by the case of Sudan, established in 1956, as well as South Sudan, established and seceded from the former in 2011. Indeed, Sudan-in contrast to Germany, Congo, and Korea - could never be considered as a unified country throughout modern history. Its northern and southern regions have significantly differed from each other in terms of economy, culture, and religion. Consequently, the formally similar state names-Sudan and South Sudan-refer to substantively different countries.

The same applies to Macedonia, which was established and named as an independent modern state in 1991 and, following a long name dispute, ${ }^{47}$ was renamed North Macedonia (Северна

on Geographical Names, First Session, UNGEGN, List of Country Names, U.N. Doc. GEGN.2/2019/13/CRP.13 (Mar. 15, 2019), https://unstats.un.org/unsd/geoinfo/UNGEGN/docs/1st-session/GEGN.2_2019_13_CRP.13_UNGEGN_WG_Country_Names.pdf [hereinafter UNGEGN List of Country Names 2019].

${ }^{45}$ The reason for the difference is purely personal: These lists are prepared basically by the convenors of the Working Group on Country Names of UNGEGN, and the lists, if specific names are not concerned, seem to reflect their preferred vocabulary. In 2002, this function was accomplished by the Frenchwoman Sylvie Lejeu, whereas in 2019, it was accomplished by the American Leo Dillon and the Frenchwoman Élisabeth Calvarin as co-convenors. From the introductions to the lists, it is clear that these excellent professionals as practitioners have completely different vocabularies.

${ }^{46}$ As to the struggle for the name of Germany by the two German states during and directly after the Cold War, see Stephan Jaschek, Zum Namensrecht der Staaten: Heißt es Bundesrepublik Deutschland oder Deutschlands?, 25 VerEINTE NATIONEN: German rev. on the U.N. 135-38 (1977). See also Helmut Berschin, Deutschland—ein Name im Wandel: Die Deutsche Frage im SPIEgel Der Sprache (1979); Helmut Berschin, Wie heißt das Land der Deutschen, 13 Deutschland ARChiv 61-77 (1980).

${ }^{47}$ On the early stages of this name debate see Demetrius Floudas, A Name for a Conflict or a Conflict for a Name? An Analysis of Greece's Dispute with FYROM (1991-1996), 24 J. POL. \& Mil. SocIo. 285-321 (1996); Igor Janev, Legal Aspects of the Use of a Provisional Name for Macedonia in the United Nations System, 93 AM. J. INT'L L. 155-60 (1999). From the extensive and comprehensive literature on the dispute over the name Macedonia, see Nikos Zaikos, The Onomastics of States in International Law: The Case of the Former Yugoslav Republic of Macedonia, in MACEDONIAN IdENTITIES THRough TIME-INTERdisciplinARY APPROACHES 337-61 (2010); Michael Ioannidis, Naming a State: Disputing over Symbols of Statehood at the Example of 'Macedonia,' 14 MAX PLANCK Y.B. U.N. L. 507-61 (2010); Ilja 
Македонија, Severna Makedonija) in 2019. The cohesion of this state, with the three regions belonging to the northern province of Greece and designated with the attribute "Macedonian,"

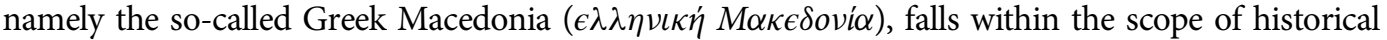
myths at best, the same way as does its opposite. This is despite the brief historical rise and splendor of an ancient people and the ancient Macedonia twoandahalf thousand years ago. Nevertheless, the name dispute was inevitable because the name of a state not only has designating or descriptive, but also legitimizing and identity-creating, or at least identity-reinforcing, functions. ${ }^{48}$

Needless to say, it is also possible that a formally similar name does not mean economic, political, or cultural community between two states as well as their peoples and territories, as is well-known in the case of Nigeria and Niger, which were named after the river flowing through both countries. ${ }^{49}$

The semantic difference between the country name and state name is facilitated by the dual meaning of the English word country, which originated in the 13-14th centuries when it became distinguishable from the Old French word contree. On the one hand, it refers to a cohesive geographical territory and, on the other hand, to the institution, power, and organization, thus to the state, that unites the territory together with the people living there. The word country means both territory and institutionalized power exercised over the people living there. The meaning of the former is stronger and firmer than that of the latter. When conflict arises between the two meanings regarding countries, the latter becomes subordinated by the former or simply disappears.

The word "state," which has been known in its current meaning since the $16-17$ th centuries, ${ }^{50}$ also has a dual meaning: Primarily, it refers to an institutionalized power, and secondly to a cohesive geographical territory as well as the population living there. ${ }^{51}$ In the case of a conflict between the two meanings regarding states, the geographical element becomes subordinated by the institutional one or remains in the background. In other words, the two meanings of the word may and often do become separated: There are countries that no longer, not yet, or currently do not constitute states, while there are states that cannot yet or currently cannot be regarded as individual countries.

In everyday language usage, such differences are often overseen or not attributed significance. For example, in a statement like "Frédéric Chopin was born in Żelazowa Wola, in Poland" we are not concerned with the fact that at the time of Chopin's birth in 1810 the Polish state did not exist, as it had been, for a while, erased from the map by three great powers oneandahalf decades earlier. Consequently, Żelazowa Wola, situated 30 miles from Warsaw, was not located within the territory of Poland, ${ }^{52}$ but our statement still has a meaning. Thus, the word Poland may make

Milchevski, A Requiem for a Dream: The Name Issue and the Accession of Macedonia to the EU, 22 INT'L IssUES AND SLOVAK ForEIGN POL'y AfFAIRS 40-59 (2013). For an analysis in a more general, historical context of this issue, see Joseph S. Roucek, The Eternal Problem of Macedonia, 2 INT'L J. 297-307 (1947), which still has some relevance today. For a study emphasizing its political context, see Andreas Willi, Whose is Macedonia, Whose is Alexander?, 105 The ClassiCAL J. 59-64 (2009). On the hopelessness of solving the so-called "Macedonian Question," see Victor Roudometof, Collective Memory, National Identity, and Ethnic Conflict: Greece, Bulgaria And the Macedonian Question 189-210 (2002).

${ }^{48}$ In the context of the Macedonian question, see Matthew R. Craven, What's in a Name? The Former Yugoslav Republic of Macedonia and Issues of Statehood, 16 Australian Y.B. INT'L L. 199 (1995); Dean M. Poulakidas, Macedonia: Far More Than a Name to Greece, 18 Hastings InT'L \& COMP. L. REV. 397 (1995). The so-called identity-creating functions of geographical place names, in general, are discussed by Botolv Helleland, Place NAmEs and IDENTities: Oslo StUdies IN LANGUAGE 95-116 (2012).

${ }^{49}$ See Mervyn Jeffreys \& David Waldegrave, Niger: Origins of the Word, 4 CAHIERS D'ÉTUdES AFRICAINES 443-51 (1964).

${ }^{50}$ The English state, the German der Staat, the French l'etat, the Italian lo stato or the Spanish estado evolved from the Latin status but acquired a completely new meaning over the period in question. See H. C. Dowdall, The Word "State," 39 L.Q. REV. 98-127 (1923); AleXander Passerin d’Entreves, The Notion of the State: An Introduction to Political Theory 34, 42, 170-81 (1967); Alan Harding, The Origins of the Concept of the State, 15 Hist. Pol. Thought 57 (1994).

${ }^{51}$ In a similar vein, see Otto Back, Typologie der Ländernamen: Staaten-, Länder-, Landschaftsnamen, in 2 Namenforschung, supra note 1, at 1353; Otto Back, Probleme um Staatennamen, 21/II J. InT'L CounCIL OnOMASTIC SCIENCES 66-72 (1977).

${ }^{52}$ In establishing the name of a particular state in a given period, invaluable assistance is provided by the historical dictionary of state names compiled by Peter Truhart. In the context of Poland, see Peter TruHART, Historical DiCTIONARY OF STATES / LEXIKON DER HISTORISCHEN STAATENNAMEN 16.51-16.52, 16.55 (1995). For a similar undertaking, 
sense in such a statement even when and if the Polish state temporarily does not exist. Normally, the word Poland as a country name designates-besides the words Masurian Lake District, Pomerania, Mazovia (the surroundings of Warsaw) and Zakopane, etc.- the Sejm and the Senate of Warsaw, the Polish government and its offices, as well as the courts, and thus the Polish state itself.

In normal situations, both country name and state name, or state title, can be used for denominating a state because usually there is no universally valid rule for which name is or should be considered appropriate considering in different situations. Interesting and meaningful conclusions can be drawn by the sociolinguistic observation of actual linguistic usage if we observe which one is used from country to country in certain situations. For example, on maps or the cover plates of passports, in the names of nation-wide governmental institutions, on the diplomas awarded by public educational institutions or recognized by states, on the buildings and cars of diplomatic corps, in international treaties, or, to mention a seemingly marginal example, on tables at border crossing points.

The last example may be illustrated as follows: On roads approaching the borders of the territory of a state, we find signs showing in one case country names and in another case state names. In relation to these, the following can be observed in Europe. In Western, Southern, and Northern Europe, generally the country names are used-for example, France, Luxembourg, Italy, Spain, Portugal —often in the language of the state in question (Niederlande, Danmark, Norge, Swerige) or in more than one language on the same sign; for example, Suomi, Suopma, Finnland; or eventually on different signs: Belgien, Belgique, Belgieë. Here signs never signify whether the state in question is a republic or monarchy. The only exception in this region is Germany, which is never indicated on road signs with its country name (Deutschland) but always in the following way: Bundesrepublik Deutschland (Federal Republic of Germany). In contrast, approaching border crossing points in Central, Eastern, and Southeastern Europe, one is almost always confronted with state titles on signs indicating the forms of the states in question in the language of the particular country; for example, Republika Crna Gora, Rzeczpospolita Polska, Republika Hrvatska, or in two languages, Република Cрпска-Republik of Serbia, Република България-Republik of Bulgaria, Рэспубліка БеларусьRepublic of Belarus. These countries are seldom indicated by country names towards borders. The two exceptions in these regions are provided by the signs of Russia and Ukraine ${ }^{53}$ which almost always indicate the approaching of the border with their country names. Distinctively, between these two main types of border-signing, there are mixed types as well, typically in Central Europe, as in the case of Austria and that of Slovenia, and in the countries of the Baltic region. ${ }^{54}$

This is only one example of the principle that there is no general rule as to when and in what situation the different types of names should be used to designate states.

see, for the case of the Poland, John Everett-Heath, Place Names of the World: Historical Context, Meanings and CHANGes 219-22 (2000). In the context of historically existing German countries and states (Länder), see Dieter Berger, Deutsche Ländernamen in der Geschichte, 22 BEITRÄGE ZUR NAMENFORSCHUNG 129 (1987).

${ }^{53}$ Ukraine is sometimes called in English "the Ukraine," which is incorrect both grammatically and politically. Its name is stated without the definite article in the Declaration of Independence of Ukraine and in the Act of Declaration of Independence of Ukraine, both dated August 24, 1991. Additionally, the Ukraine reminds many Ukrainians of the time when Ukraine was a republic of the Soviet Union, and the word meant "borderland." In grammatical terms, there are many similar questions in English regarding the "obligatory" (see, for example, the Gambia, The Bahamas) or the conventional (the Netherlands, et cetera) use of the definite article with country names, but I cannot go into detail here.

${ }^{54}$ In the case of Austria, signs with the inscription of Republik Österreich are more widespread, while examples of Austrija, Avstrija, or Ausztria are sometimes also used. Similarly, but in reverse ratio, Slovenia is indicated with signs of Republika Slovenija, although signs with the inscription Slovenija are also common. In the Baltic region, the "mixed nature" is generally characteristic for all the three countries taken together: Estonia and Lithuania are indicated with signs reading mainly Eesti Vabariik (Republic of Estonia) and Lietuvos Respublika (Republic of Lithuania), while the country names are rarely used. Meanwhile, Latvia is indicated with Latvija even though signs reading Latvijas Republika (Republic of Latvia) occur as well. 


\section{The Names of Names}

Recapitulating all of the above-mentioned details, it can be stated that academic literature, as well as the terminological introductions to lists of states of different bodies and name authorities, employ the following seven name categories for the denomination of states:

Table 1: Name categories in possible pairs for the denomination of states ${ }^{55}$

\begin{tabular}{|c|c|c|c|}
\hline 1. & short-form of state name & - & long-form of state name \\
\hline 2. & $(-)$ & & complete form of state name \\
\hline 3. & (non-official state name) (-) & & official state name (state title) \\
\hline 4. & (informal state name) ( -) & & formal name of state \\
\hline 5. & $\rightarrow$ habitually accepted name(s) & & $(-)$ \\
\hline 6. & & & legal or constitutional state name \\
\hline 7. & COUNTRY NAME & - & STATE NAME / STATE TITLE \\
\hline
\end{tabular}

Three terms of this summary require explanatory comments.

1. The term complete or full name (German: Vollform) (line 2) does not have a pair because a non-complete name would generally be a meaningless or at least inaccurate term. After all, it is reasonable to assume that what is non-complete is not suitable for clearly identifying anything. Therefore, states/countries do not have non-complete names. Certainly, a noncomplete name may also refer to: (i) an imprecise reference with an uncertain meaning, for example, when the word America is used to denote the United States of America and is not confused with the continent due to a tacit consensus in communication; (ii) a practice established by and accepted within the linguistic tradition and thus the consideration of country names as state names under certain conditions; or (iii) an abbreviation, which can be used to precisely indicate states. For example, the abbreviations USA, U.S.A., and even U.S., or earlier, FRG and GDR, or USSR, etc.; however, they are, in fact, not noncomplete forms of state names but communicative aids. ${ }^{56}$ In these cases, the term noncomplete name might have some meaningful sense.

2. Although the pair of formal and informal state names (line 4) resembles the pair of official and non-official state names (line 3), there is a difference between them. The former pairs of categories show uncertainty in terms of the differentiation of formality and informality; in the latter case, the officialness of the name is contestable. Therefore, in the case of using these two pairs of categories, it would be impossible to maintain the principle of "one state-two names." States, just like individuals, may have various informal names. ${ }^{57}$ However, informal and formal names cannot be matched, just as official and non-official names cannot.

3. Legal or constitutional names (line 6) are sometimes paired with names used in the social or sociological sense. The constitutional names may, however, have various types in the case of states. State names in the sociological sense include - in the first place-habitually accepted (line 5) and widely used names, non-official and informal names (lines 3-4), as well as country names (line 7). Nevertheless, in the diplomatic relations between states, the legal or constitutional name becomes the "habitually and widely accepted" one, while on the supra-national level there is yet no normative system that would universally determine the official names of states.

\footnotetext{
${ }^{55}$ This table does not include the term "short geographical name of the state," which is also used once in a while. I did not add this to these lists because I did not want to complicate the table with the geographical name component. The expression "geographical name," on the one hand, seems to be an unquestionable linguistic tradition, and on the other hand, is the source of many theoretical problems in the field of state names, for it gives rise to many misunderstandings.

${ }^{56}$ The complex issue of abbreviated names as state names is not discussed here due to lack of space.

${ }^{57}$ Compare nickname, pen name, pet name, nom de plume, cognomen, code name, pseudonym, soubriquet, et cetera.
} 
It is a general and implicit rule that every state may have two names except for those with divided populations and/or territories. Currently five such states exist. ${ }^{58}$

According to a view, ${ }^{59}$ if a country name stands unaltered in the complete form of state name or if the long-form of state name serves as the country name, states and countries have one single name. This is, however, only a false theoretical conclusion drawn from the practice of lists of country names and state names. The case is rather that a name, namely one word, may appear in two functions. For example, a country name becomes, if there is nothing else, a state name, while a state name becomes, if there is nothing else, a country name. Therefore, they are equivalent. States have, even in these cases, two names; namely, they have a country name and a constitutional name even though only one word or one combination of words is said, heard, or read as the name. In these cases, the two names are equivalent. That being said, there are five special cases when a state-due to political divisions-does not constitute the territory of the whole country. This issue is examined in detail below.

There is no binding rule as to which of the above-mentioned terms describing types of names shall be applied to states. In the practice of spoken languages, country name and state name are generally employed applying the semantic relation between country and state while their semantic anomalies are corrected with the terms indicated in lines 1-6 above. There are, however, only two of them-namely those included in line 1-that constitute a pair. They can thus be used without semantic distortion. These are really complementary terms. The terms in lines 2-6 are frequently mixed even by national name authorities and international experts of the topic - a practice that may lead to the confusion indicated above.

The conceptual overlapping and terminological challenges cannot be solved solely by linguistic tools or by the semantic maintenance of terms. It requires the reference to some public law components as well, and a more consistent naming system of states can be developed only with regard to these components. The possibility of developing such a system is dealt with below.

\section{E. A Framework for the Naming System of States Based on Their Naming Practice}

The consequent framework for the system of state names or name regime ${ }^{60}$ - complying with grammatical rules and corresponding to the languages actually used-can only be developed and maintained if semantically equivalent terms (matched in the table above) are employed in the denomination of states, including the frequent case when they are used to correct the difference in meaning of the words country and state. Because in the semantic sense, only short (shortform of) and long (long-form of) names of state can be matched undistorted, ${ }^{61}$ whereby sometimes the latter is perceived as complete or Voll form of the state name. As a result, in this Article I only use these two terms without calling the long-form "official name," "formal name," "legal name," or "constitutional name"; however, I take into consideration their substantive elements in the development of the system. ${ }^{62}$

\footnotetext{
${ }^{58}$ Ireland, Democratic Republic of Congo, Republic of the Congo, Democratic People's Republic of Korea, Republic of Korea.

${ }^{59}$ See Gábor Gercsák, Térképi névirás [Writing Names on the Map], in CARTOGRAPHY AND GEOINFORMATICS 223 (2010); Albert Takács, Alkotmány-Államtan. Kormányzati tanulmányok [Constitution-Theory of State. Studies on Government] (in Hungarian) 51 (1st ed.) and at 65 (2d ed.) (Budapest NKE VTI, 2016 and 2018). For my critique of this view, see Takács, supra note 25 , at 17 .

${ }^{60}$ The naming system (name regime) constitutes the structure of the various elements of the name in different languages, cultures, and legal systems. In the case of individuals, it includes the sequence of given name and surname, as well as other name types, such as generation name or paternal name, with rules relevant to the optional or possible abbreviated nature of one or the other element, et cetera. For the naming system of individual human beings, see Edwin D. Lawson et al., Personal Naming System, in The OxFord HandBooK of NAmes AND NAMING, supra note 1, at 169-98.

${ }^{61}$ I expressed this supra Table 1, Line 1.

${ }^{62}$ For a different typology of country names which are or can be conceived as state names, see 2 NAMENFORSCHUNG, supra note 1 , at 1350-52. This theory could not be applied or utilized here due to the fact that it does not analyze the names in
} 


\section{Main Elements of the System}

The main argument of this Article can be summarized as follows: Based on the relationship between country names - as short-forms of state names_and state names-long-forms of the state name or state titles in British usage-we can differentiate three main ways of denominating states.

\section{Regular Cases}

In cases belonging to the first group, ${ }^{63}$ the short-form of state name is the country name while its long-form is the actual state name, or state title. This is the most common, regular, or ordinary case of forming a name for state, with one hundred and sixty-five states belong to this group.

Five subtypes can be distinguished within this group according to whether the actual state name: (i) indicates the form of state, or the so-called state-form-form of government ${ }^{64}$ - for example, republic or monarchy; (ii) refers to the so-called structure of the state, ${ }^{65}$ which usually expresses the degree or level of state unification that can also manifest in public law, for example, unitary state, federation, confederation, union, etc.; (iii) employs both, for example, federal or federated republic, united republic, united kingdom, etc.; (iv) refers to the type of institution that expresses the political coherence of a community with a seemingly neutral term, for example, whether it is a state or commonwealth; and (v) supplements any of these with a reference to a political, religious, or ethnic factor, for example, socialist, democratic, or people's, Islamic, Arab, Hashemite, oriental or Bolivarian, co-operative, pluri-national or independent. ${ }^{66}$

\section{Naming Countries by State Name and Naming States by Country Name}

The second main type ${ }^{67}$ consists of states which possess a long-form of state name but have no country name; thus, they seemingly have no short-form of the state name either. In other cases, the country name of these states corresponds to their state name. Thus, they seemingly have no long-form of the state name. Twenty-five states belong to this group. As I argued above, possessing one single name is only a communication illusion in these cases for the same word, or name, which fulfills two functions. Implicitly, this indicates two modes of forming a name: (i) when a country is named after the long-form of the state name, thus by replacing the country name with the long-form of the state name, or (ii) when the long-form of state name is replaced with the country name.

Cases belonging to the first group (i) are consequences of a special situation for historical reasons. The reason why these names developed the way they did is that it was attempted to prevent the reference of the country name to the territory of two states whilst there were no political divisions; or it was attempted to find a solution to the denomination of states which did not possess a country for reasons of continuous historical developments or themselves do not constitute a state of a single country or involve more.

questions in terms of public law components but primarily in the framework of traditions of geographical names and cultural factors. For the possibility of a grammatical or lexical classification, see Dieter Berger, Morphologie und Wortbildung der Ländernamen, in 2 NAMENFORSCHUNG, supra note 1, at 1356-61.

${ }^{63}$ See infra case 1 (regular cases) in Table 2.

${ }^{64}$ Throughout this Article, the terms "form of state" or "state-form" (German: die Staatsform, French: les formes d'Etat) are used to designate the public law structures that reflect and reinforce the most significant elements of political relations, mainly in relation to, and expressed by, the selection, responsibility, and status of the head of state. In this general sense these formsalthough they have several classifications and typologies - have been divided into two main categories_ "monarchy" and "republic" - since the 16th century, whatever we may hold about their value in contemporary political science. In the English language literature, this general meaning of the form of state is also expressed by the term "form of government," for example German: Regierungsform, French forme de gouvernement.

${ }^{65}$ The term "structure of state" is mainly used in the German-language literature as Staatsstruktur. See, e.g., THOMAS Fleiner \& Lidija Basta Fleiner, Allgemeine StaAtslehre: Über die konstitutionelle Demokratie in einer MULTiKulturelLEN GLOBALISIERTEN Welt 578-79 (2004).

${ }^{66}$ For a similar, but not quite the same, sub-typology of state titles as "states' official names" see Brunner, supra note 3 , at $2-13$.

${ }^{67}$ See infra case 2 (non-regular cases) in Table 2. 
Due to the specific nature of circumstances, only three states can be classified as such: The Dominican Republic, the Central African Republic, and the United Arab Emirates. ${ }^{68}$ Furthermore, before July 1, 2016, the Czech Republic was also a member of this group inasmuch as in several languages, including Czech, the long-form of state name was used as a country name, that is Czechia today. For this reason, Czechia had long been called a country "looking for her name" or, with much exaggeration, "a country with no name." 69 The details of this issue-with the country names of Czech Čechy, lately Česko, or Morava (Moravia) and Slezsko (Silesia, more precisely, Czech Silesia), as well as with the tradition of English Bohemia and German Böhmen, Czechia, and Tschechien - are so complicated that it is impossible to explain it in detail here. And perhaps there is no need for it. After all, the "no-name country" situation ceased four years ago.

The second group (ii) of the second main type is the inverse of the former: For some reason, the country name is employed here as the state name, and the state name contains no reference to the form and structure of state or the type of institute representing the political community or their ethnic, religious, or political supplement. In these cases, the state name-for example, Japan, Hungary, Mongolia, Montenegro, or Malaysia-concurs with the country name. In other words, in naming of such states the long-form of state name is replaced with the short-form of the state name. As mentioned above, in the case of these states the functions of the long-form of the state name-for example, in diplomacy or in the analysis of international legal circumstances-are performed by the country name which can be regarded as a state name in this function. The complicated question, facilitating several explanations, of why this naming mode evolved is examined in the framework of a different study, and it was evaluated above in the context of the 2011 renaming of Hungary.

\section{Special Cases}

The third way of naming a state in the system of state names, ${ }^{70}$ is used when countries are divided into two political and state entities, and this division persists for such a long time that it needs to be expressed by names as well. As mentioned above, such country names are replaced by a reference to either an orientation-compare Korea with earlier Germany-or some other additional criteria-compare Congo. Currently, five states belong to this group: Two divided, so-called pseudo countries, parts of which did not belong together for decades, as well as Ireland, an imaginary unitary country whose two parts belong to two states in actual political reality.

\section{Overview}

Summing-up and recapitulating all of the above statements, I survey individual cases, illustrate them with two examples and, incidentally, note the number of cases specified for each category. See Table 2.

As to the number of possible cases of all states, I rely on the theories widely accepted in the academic literature of theory of state (Staatslehre) and political science. This means that I disregard the so-called pseudo-states, ${ }^{71}$ proto-states, ${ }^{72}$ shell states, $^{73}$ state fragments, ${ }^{74}$ and nasciturus

\footnotetext{
${ }^{68} \mathrm{~A}$ long time ago, at the turn of the 18th and 19th centuries, the United States of America also belonged in this classification, before the use of the name United States became widespread as the country name.

${ }^{69}$ See these exaggerated terms in Daniela Lazarová, Looking for a Name, RADIO PRAGUE INT'L (May 13, 2004), https://www. radio.cz/en/section/curraffrs/looking-for-a-name; PETR BERKA ET AL., THE XeNOPHOBE's Guide TO THE CZECHS 1 (2011).

${ }^{70}$ See infra case 3 (special cases) in Table 2.

${ }^{71}$ On the term "pseudo-state," see, for example, Barry Sautman, "All that Glitters is Not Gold:" Tibet As a Pseudo-State, 198 MD. SERIES IN CONTEMP. ASIAN STUD. 127-42 (2009).

${ }^{72}$ On the term "proto-state," see, for example, Anicée Van Engeland, Statehood, Proto States and International Law: New Challenges, Looking at the Case of ISIS, in The International Legal Order: Current Needs and Possible Responses: Essays In Honour of DJAmchid MomTAZ, 75-88 (James Crawford et al. eds., 2017).

${ }^{73}$ For the origin and the first use of the term "shell state," particularly in the case of Nigeria, see KenNETH C. OMEJE, HigH Stakes and Stakeholders: Oil Conflict and Security in Nigeria 48 (2006).

${ }^{74}$ The term "state fragment" (German: Staatsfragments) was introduced by Georg Jellinek. See GEORG JELLINEK, Allgemeine StaAtslehre 657-60 (3d ed. 1914). Its meaning slightly changed later, but I use it in its original sense.
} 
Table 2: Framework for the naming system of states, based on their naming practice

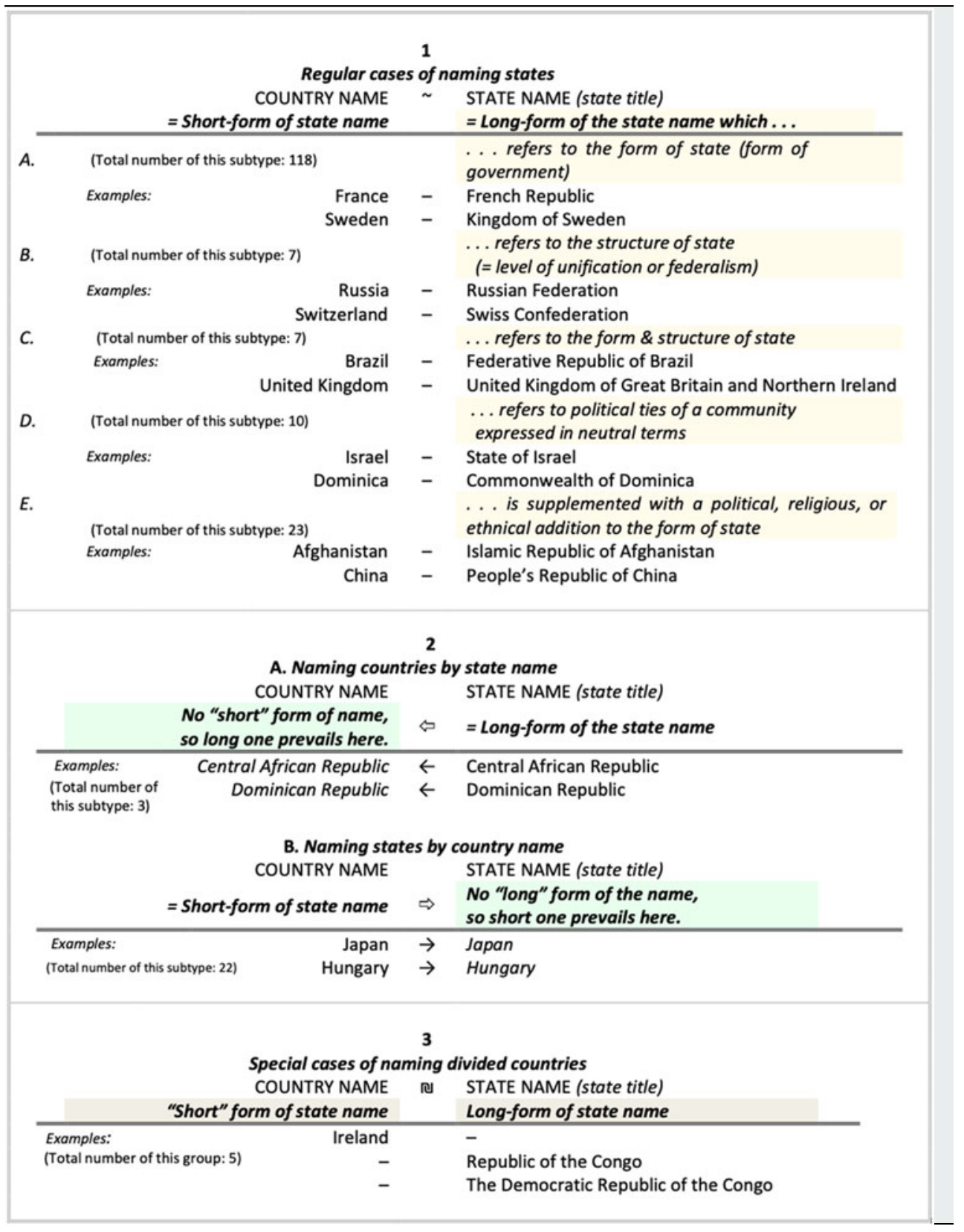

states, ${ }^{75}$ etc., which, in essence, fall between the categories of states and non-states. However, they cannot be considered to be states because they do not possess all the accepted criteria of statehood. ${ }^{76}$

\footnotetext{
${ }^{75}$ On the term "nasciturus state," see CRAWFORD, supra note 10, at 663-64.

${ }^{76}$ Although this reservation is well-established, some would still object if Kosovo (Republic of Kosovo) is taken into account in the classification and may feel the absence of Taiwan (Taipei or Chinese Taipei; namely, the Republic of China), Western Sahara (Sahrawi Arab Democratic Republic), Palestinian National Authority or Tibet (Central Tibetan Administration), to mention just a few of the problem cases. These are politically sensitive issues whose theoretical settlement cannot be included
} 


\section{Examples of Cases and Further Details}

\section{Regular Cases of Naming States}

\subsection{The Five Main Types and the Number of Cases Involved}

The first main group includes 165 states. ${ }^{77}$ In these cases, both country names and long-forms of state names can be used for the denomination of states. Consequently, renaming the state does not necessarily mean renaming the country, although, in this regard, North Macedonia might be an exception and possibly needs further specification.

118 states out of 165 fall under the group's first category (1/A). These include ninety-nine states that indicate in their names solely that they are republics, as well as nineteen that indicate that they are monarchies - fourteen kingdoms, three principalities, one grand duchy, and one sultanate; and their names do not indicate anything else.

Seven states can be included in the group whose names indicate solely their state structure and seven others whose names refer to both their state structure and form of state but nothing else. The former ones within 1/B are, according to their names, either unions; federations, which include confederations; united; or eventually federated states. ${ }^{78}$ The situation of the United States of America is unique in this group. Its name was originally included in group 2/A because-besides the fact that its long-form of state name slowly became steady and for some time it was translated into various languages in highly diverse forms-it had no historically shaped separate country name for a while. Nevertheless, the linguistic practice soon decided that the country name had become the short version of the long-form of state name: United States. The fact that the moniker "U.S.A.," carved in or written on military equipment, was replaced by the moniker "U.S." during the 19th century, played a significant role in this regard. Perhaps this illustrates a lack of foresight that this army would be deployed outside the American continent. ${ }^{79}$

States in the latter group, group 1/C, include united, federal, or federative republics and kingdoms. For instance, the Federative Republic of Brazil, the Federal Republic of Germany, the United Republic of Tanzania, plus the United Kingdom of Great Britain and Northern Ireland fall within this group. The United Kingdom — at least for the external language users - constitutes a further special case because, by reason of its complexity and socially widespread but inaccurate country name versions_-namely Britain, sometimes England, etc.—its names are commonly used as the informal state name in many languages.

Ten states belong to the fourth subgroup of the first group, group 1/D, of which names contain neither form nor structure of state but refer to the political cohesion of the community with some neutral or seemingly neutral term in their name. Five states in this group are states by their name: State of Israel, State of Kuwait, State of Eritrea, State of Libya, and State of Qatar; three are commonwealths: Australia, The Bahamas, and Dominica; one is city state: Vatican, known as the Vatican City State $;^{80}$ and one constitutes a very special case: Brunei-Negara Brunei Darussalam, and also Nation of Brunei, the Abode of Peace.

in such a short study on names of states. For further disputed cases in James Crawford's list, see CRAWFORD, supra note 10, at 727-40.

${ }^{77}$ Ascertaining the number of states is a complex problem in the theory of state, political philosophy, and theory of international law which obviously cannot be explicated here. I note, however, that the answer depends on whether or not we define "state" independently of the status of the UN member state (193). Apart from the well-known example of Vatican City State, the key issue here is whether political units that consider themselves "states" but not yet universally or widely recognized by other states (such as Kosovo) should be included here. Another typical problem is the supposedly ceasing and apparently disappearing states or state-like entities (for example, Western Sahara). There is, of course, no place to explain these theoretical problems here. The numbers mentioned here are based on the number of 195 (total) states.

${ }^{78}$ For instance, the Union of the Comoros, the Russian Federation, the Federated States of Micronesia, the United Mexican States, and the United States of America.

${ }^{79}$ There is extensive literature available on this issue, but it cannot be discussed here in detail. For a short summary, see Edmund C. Burnett, The Name "United States of America," 31 The AM. Hist. Rev. 79-81 (1925).

${ }^{80}$ On the name of Vatican, see Thomas J. Reese, Inside the Vatican: The Politics and Organization of the CATHOlic Church 5-6 (1998); CrawFord, supra note 10, at 227-30. 
Finally, twenty-three states are included in this first main group, group 1/E, of which names refer to the form of state-or in one case, kingdom, while in all other cases, republic - and eventually to the state structure as well. In the case here concerned, it is federal; meanwhile, they are supplemented with a religious, ethnical, political, or historically interpretable political additions.

Because in the historical sense today it is no longer necessary to elaborate on the terms concerning the form of the state-for example, the republic and monarchy—or the structure of the state-for example, federations, confederations, unions, etc.-I will detail only some problems of the latter two subgroups.

\subsection{Politically Neutral Terms in the Names of State}

States that do not want to indicate the form or structure of the state in their names, or simply do not want to take a stand on these important issues, have two options: (i) name themselves by the country names - if it is possible to, grammatically and/or politically - or (ii) use a neutral, or seemingly neutral expression in their names. In this regard, the following three terms may come into question: "Free state," "state," and "commonwealth." The concept of neutrality changes over time, so today only the second and third can be classified here; the first is considered incompatible with both republican and monarchical forms of state because it got too close to one of them.

\subsubsection{The Term "Free State"}

Initially, at the emergence of the term "free state" around 1646 in English and around 1731 in German, it referred to an independent political community — for example, Switzerland — while later it indicated some substantially and genuinely new principle upon which the political community could be based. For example, Maryland in the United States of America was recognized as a free state in 1864 on the basis of its new constitution, which abolished slavery within the state's borders and thus achieved equality of rights between people of different colors. In Europe at the same time, the genuinely new political principle was the republican ideal with the possibility of practical implementation in the sense that the form of a state does not necessarily have to be monarchical. So, during the 19th century, the term free state became synonymous with the word republic. To that effect, nearly all of the member states of the Weimar Republic - to use an unofficial historical designation for the German state between 1918 and 1933 - became free states in 1918 and 1919. Besides the three free city states_-Freie und Hansestädte, historically Hamburg, Bremen, and Lübeck-there were two exceptions: The Grand Duchy of Baden became the Republic of Baden and the Grand Duchy of Hessen became the People's State of Hessen (Volksstaat Hessen). ${ }^{81}$ The other seventeen states chose to be free states instead of republics because it was supposedly easier to gain acceptance for the republican form of state under that name. Later, in the German language usage of the 20th century, this term referred not only to the form of state, otherwise known as the form of government, but also to a certain way of the distribution of power. Thus, it indicated willingness towards federalism. Based on this meaning, Saxony (Freistaat Sachsen) and Thuringia (Freistaat Thüringen) have chosen to be free states in their names some years after 1990. The case of Bavaria (Free State of Bavaria, German and Bavarian: Freistaat Bayern) is in outlier in this regard given that its name has remained unchanged since $1945 .^{82}$ Bavaria has been a free state since the Bamberg Constitution in 1919. In 1922, more or less for the same reasons, the state born on the southern side of the island of Ireland was given the name Irish Free State, which was used until the adoption of the 1937 Convention, by which the new state took the name Ireland.

\footnotetext{
${ }^{81}$ There was also a third state that did not use the term free state in its name; namely, the merger of the Principality of Reuss Elder Line (German: Fürstentum Reuß älterer Linie) and the Principality of Reuss Junior Line (German: Fürstentum Reu $\beta$ älterer Linie), called People's State of Reuss (Volksstaat Reuß). But this state existed only for one year and merged into Thuringia in 1920.

${ }^{82}$ For these issues, see Johannes Merz, “Freistaat Bayern:" Metamorphosen eines Staatsnamens, 45 VIERTELJAHRSHEFTE FÜR ZEITGESCHICHTE 121-42 (1997).
} 


\subsubsection{State}

Most of the states that included the word state in their long-form of state names at the time of their establishment or independence-in the case of Israel in 1948, in the case of Kuwait in 1961, in the case of Qatar in 1971, and in the case of Eritrea in 1993-have chosen this term because they were presumably confronted with the problem that the accurate assessment of their territory and judging the minimum standard of the unity of the people living there and united by them were the subject of debates. The fifth such state, Libya-independent from 1951 and renamed as the State of Libya in 2018 - became subject to this kind of debate during the civil war which started in 2011. It is no accident that these states are located in the Middle East, including the Arabian Peninsula and certain North African territories, where political stability and lasting social order are particularly fragile values. ${ }^{83}$ In this region, the word state, as opposed to kingdom, principality, alliance, not to mention republic, suggests the idea or the desire to establish a state of firm, stable and indisputable political unity.

\subsubsection{Commonwealth}

The third neutral or seemingly neutral term, commonwealth, may refer to a great many things, so it does not make it easy to formulate clear statements about its meaning in the context of the names of states. Its current use in naming political units is scattered and its context has been obscured by history. Presently, the word refers to two international organizations-one is British post-colonial, the other is Eurasian post-Soviet-both aiming at the integration of states in some way. ${ }^{84}$ Further it is used for naming American semi-autonomous territories, ${ }^{85}$ towns with special status, ${ }^{86}$ and a special district of a city. ${ }^{87}$ And listing all of these I did not even mention that the term may appear in the title of artwork and books ${ }^{88}$ with a puzzling and abstruse message as well. In addition to all of this, the term refers to a certain kind of state long ago.

\footnotetext{
${ }^{83}$ There is no reason to classify those states in this group which have the word state in their name, but only as a subordinate element, compared to other denotations (such as the "united" or "federated") or expressing secondary information relative to which there is something more important (such as the proudly proclaimed "independence" or the recorded and accepted multi-ethnicity). For the former, see, for example, the United States of America, the Federated States of Micronesia, and the United Mexican States. And for the latter, see, for example, the Independent State of Papua New Guinea, the Independent State of Samoa, and the Plurinational State of Bolivia.

${ }^{84}$ See the British Commonwealth of Nations, which is a political, economic, and cultural association of 53 states, most of them are former territories of the British Empire, and the Commonwealth of Independent States (Russian: Содружество Независимых Государств), which is a political alliance of 10 Eurasian states that became independent after the dissolution of the Soviet Union. The former is an association of different states, and its name replaced the British Empire in certain contexts, and the latter is a confederation, in fact an alliance, of states; in a sense, in part it substituted the Soviet Empire. The former empire took legal form, so it had well-defined but frequently changing names, composed of different kinds of dominions, colonies, protectorates, and mandates. The latter was basically a political phenomenon so it had only loosely applicable names, composed of military "alliance," "council for mutual assistance," and the like, each of them misleading. In a sense, the same is true of the names of their successors. On the name and naming the British Commonwealth, see Hessel Duncan Hall, Commonwealth: A History of the British Commonwealth of NATIONS 189-92, 648-51 (1971).

${ }^{85}$ These are Puerto Rico and the Northern Mariana Islands as self-governing U.S. territories which are not states. For a while, even the Philippines was named in this way (1935-1946), but it became an independent state in 1946, and since then, it has been referred to as the Republic of the Philippines.

${ }^{86}$ See the settlements named Commonwealth of Virginia and Wisconsin, United States of America.

${ }^{87}$ See the special zone in Queenstown, Singapore, which was named after the British Commonwealth of Nations, for the same reason Queenstown was named after Queen Elizabeth II in 1952.

${ }^{88}$ See, for example, the statue on the Pennsylvania State Capitol grounds (1905), the novel of JOEY GOEBER, Commonwealth (2008), that of Ann Patchett, Commonwealth (2016), and the analysis of Michael Hardt \& Antonio Negri, The Commonwealth (2009), explicating something important expressed in figurative speech in the third piece of their trilogy.
} 
After these various occurrences, it is slightly surprising that currently the word commonwealth is used only in the name of three states-Australia, The Bahamas, and one of the two Dominicas - and in the name of four member states of the United States: Kentucky, Massachusetts, Pennsylvania, and Virginia. Do these seven states have anything in common? They are located on different continents and one of them is a continent in and of itself. Those situated in the same region, the West Indies, differ in their governmental system: The Commonwealth of Dominica is a parliamentary republic and the Commonwealth of The Bahamas is a parliamentary monarchy. One is a unitary state, the other is federal, and four of them are members of a federation. Despite these differences, they have one thing in common: By their name, all of them are all connected somehow-through very casual yet intricate threads - to the historical situation of 17th and 18th century Britain, and its later colonial political culture, where this word became a special denomination of a certain kind of state.

"In early modern anglophone political writing," stated by Jonathan Scott in his analysis of the history of ideas, "the word 'commonwealth' was ubiquitous. It was also, until the mid-seventeenth century, uncontroversial. Capable of referring to the public social or political community, or both, to invoke commonwealth principle was to subscribe to the... commonplace that, whatever its constitutional form, government must be directed to the public good. In a related sense 'commonwealth' was the English rendering of the Latin res publica, meaning 'public thing' ..." 89 Thomas Hobbes, James Harrington, and Marchamont Nedham used it frequently as an equivalent of state, and considered it not only a state but a true, free, or ideal state as well. During the English rebellion, this uncontroversial character was eliminated by the death sentence of Charles I and by the establishment of the Commonwealth of England in 1649 as a republic. It took at least oneandahalf or two centuries to tilt the balance and to make it clear that this word, even if linked to republicanism, would not be synonymous with republic. ${ }^{90}$

If it is used in the name of a state today it implies some very general principles: That the state is based on the consent of the people, so it should serve the welfare of the public, and that it is neutral to the forms of state and even to political systems. This third principle was confirmed, and even strengthened, by the still unfinished debate on the constitutional character of the crowned republic, the Commonwealth of Australia, during the 1990s, where the name of the state was seen, and interpreted, as a camouflage; hiding a republic that is monarchical and hiding a monarchy that is almost republican. ${ }^{91}$ It is well known that the Australian public opinion is very fickle and volatile in this regard; it tilts towards monarchy, and then towards republic. ${ }^{92}$ So their state should be denominated commonwealth.

\subsection{Religious and Political Additions in the Names of State}

Names are not only for identifying and addressing states, but also for community-building, so it is not uncommon to supplement the names of states with religious and political terms. Although these qualifications - from which particular states even employ two, for instance people's democratic or democratic socialist_ - can be epistemologically problematic, they have a unique function: They intend to contribute to the legitimacy of the state's social and political order.

Religious additions include, for instance, markers of an Islamic republic, of which there are four cases, the Islamic Republic of Afghanistan, Islamic Republic of Iran, Islamic Republic of Mauritania, and Islamic Republic of Pakistan; and a Hashemite kingdom, of which there is

\footnotetext{
${ }^{89}$ Jonathan Scott, Commonwealth Principles: Republican Writing of the English Revolution 34 (2004).

${ }^{90} \mathrm{~A}$ word with similarly multilayered meanings is the Polish reczpospolita, also a translation of Latin res publica. This was used to denominate the Kingdom of Poland and the Grand Duchy of Lithuania (1569-1795), the so-called Polish-Lithuanian Commonwealth, whereas now, after 1989, it is applied for the Third Republic, mentioned frequently as III Rzeczpospolita. On one of its aspects, see Thomas Kamusella, The Politics of Language and Nationalism in Modern Central Europe 368-74, 647-48 (2008).

${ }^{91}$ On this question, see the works mentioned in the bibliographical references of the special issue in AUSTRALIA, REPUBLIC or Monarchy? Legal and Constitutional Issues 283-85 (Margaret Anne Stephenson \& Clive Turner eds., 1994).

${ }^{92}$ Clive Bean, Public Attitudes on the Monarchy-Republic Issue, 28 Austl. J. Pol. ScI. 190 (1993).
} 
one case, the Hashemite Kingdom of Jordan. Ethnic additions are comprised of, among others, Arab markers, of which there are two cases, the Arab Republic of Egypt and the Syrian Arab Republic; and multi-ethnic or, as it were, pluri-national, of which there is one case, inclusive in meaning: The Pluri-national State of Bolivia.

The political addition found in state names takes one of the following three forms. First is the substantive political qualification of the community in the traditional sense; people's, democratic and socialist, or some combination of them. For classifying a state as democratic, see Democratic Republic of Timor-Leste and Democratic Republic of Sao Tome and Principe. For federal democratic, see the Federal Democratic Republic of Ethiopia and the Federal Democratic Republic of Nepal. For people's democratic, see the People's Democratic Republic of Algeria, the People's Republic of Bangladesh, the People's Republic of China, and Lao People's Democratic Republic. For socialist, see the Socialist Republic of Vietnam. Finally, for democratic and socialist, see Democratic Socialist Republic of Sri Lanka. ${ }^{93}$ Second is its formal characterization by the words of independent or co-operative, whatever the latter means, such as Independent State of Papua New Guinea, Independent State of Samoa, ${ }^{94}$ and the Co-operative Republic of Guyana. Third is the interpretation and qualification of the community in a historical context, ${ }^{95}$ such as Bolivarian and oriental republic: The Bolivarian Republic of Venezuela and the Oriental Republic of Uruguay.

\section{Naming Countries by State Name and Naming States by Country Name}

The second case of the naming system seems to be the simplest, but this is the one that has the most complex and complicated relationships behind it.

The first group, group 2/A, is composed of three states. Apart from those mentioned as examples on Table 2 above, the United Arab Emirates belongs here. In these cases, partly because of the artificially constructed nature of these states, we do not find the fully ripened country behind the states, that evolved and developed organically for a long period of time, when the population and territory could have merged into one political entity, ${ }^{96}$ and would have forced both the native speakers and the international community to use a completely unique country name.

The second group, group $2 / B$, is composed of twenty-two states. In creating appropriate subgroups of those which have been assigned to this group, important conclusions can be drawn. Aside from a minor spelling note, ${ }^{97}$ I mention three.

\footnotetext{
${ }^{93}$ I have not counted here the "democratic" and "democratic people's" republics, namely that of the Congo and of Korea.

${ }^{94}$ I classified these two "independent states" here, and not into the group of 1/D, because in their case, the term "independent" seems to be a more prominent and pronounced supplement of the country name than the "state."

${ }^{95}$ In the long form of Uruguay's name, the adjective "oriental" needs some explanation. In this name, the meaning of "oriental" is "historical" in a special sense: It preserves historical memories. The reason for the name is that in Spanish colonial times, the territory of the country belonged to the provinces of Banda Oriental (Eastern Bank) and Cisplatina, which was a Brazilian province. The center of the territory, a Spanish military fortress, designated as the administrative center, was located east of the Uruguay River. Before gaining independence, this territory had been called Eastern Province, after that la República Oriental del Uruguay (the Eastern Republic of the River Uruguay).

${ }^{96}$ As to the organic development and ripened nature of a society behind the state, I refer to the essential core of social philosophies and theories of the turn of the 19th and 20th centuries; for example, that of Otto Friedrich von Gierke and Ferdinand Tönnies, which can still be sustained today, at least to a certain extent.

${ }^{97}$ Saint Lucia, as well as Saint Vincent and the Grenadines, may form a subgroup, the peculiarity of which is the special abbreviation and the spelling in official British English. In the case of the former, St. Lucia is considered a country name which comes from the state titles of Saint Lucia. In the case of the latter, St. Vincent could be considered the country name, and Saint Vincent and the Grenadines is the state title. Maybe it is just a consequence of the fancy of the Permanent Committee on Geographical Names for British official use. There is no such difference between these forms of names on the UNGEGN list, where both countries and states are named Saint Lucia and Saint Vincent and the Grenadines respectively, or in the German language, where the Ständiger Ausschuss für Geographische Namen decided to abbreviate the word "saint" in both forms of names. See Country NAMES, supra note 19, at 9; LISTE DER STAATENNAMEN, supra note 20, at 12; and (the 2019) UNGEGN List of Country Names 2019, supra note 44, at 80-81.
} 
2.1.

Twelve states within this category had, at one time, been colonial countries. Two of them, Canada and New Zealand, were so-called charter or crown colonies with Dominion status before gaining independence. ${ }^{98}$ Ten, with one exception, had gained independence from the remnants of the British colonial empire in the second half of the 20th century between 1960 and 1981. These are Antigua and Barbuda; Barbados; Belize; Grenada; Jamaica; Saint Vincent and the Grenadines; Saint Lucia, the now sovereign state which was earlier called Helen of the West Indies and changed hands between the British and the French many times; Solomon Islands; and Tuvalu. ${ }^{99}$ Many of them are located in Central America and its archipelago, the West Indies and Lesser Antilles; in the Caribbean Sea; and some in Oceania. Looking at this list, it is impossible not to conclude that this naming practice somehow might be related to the British colonial culture, and to these countries' post-independence form of state.

\section{2.}

Eight states employing the country name also as state title have one common historical feature as well: They were formerly so-called socialist or communist states or member states of such states. They are located either in East-Central Europe-such as Bosnia and Herzegovina, Hungary, Montenegro, Romania, and the Ukraine-or in the periphery of the former Soviet Union-Georgia, Mongolia, and Turkmenistan. This may suggest that the evolution of their names can only be explained by the political traditions of these states. All of the states listed here are republics, but their names are chosen so that they do not even accidentally include the word republic. From this it is impossible not to infer that one of the reasons for following this naming practice is intended to avoid the use of the word republic in public discourses. I discuss the case of Hungary in a separate study.

\section{3.}

Two unique names of states are included in this group. Japan's name can be explained by its very distinctive history. ${ }^{100}$ Malaysia's name can be explained by its very special state structure combining monarchical elements with a bit of republican taint.

\section{Special Cases of Naming Divided Countries}

The third group includes five states connected with three permanently politically divided countries. These are the two Koreas: North Korea and South Korea; the two Congos, Congo, or as it is sometimes called even now: Brazzaville-Congo, ${ }^{101}$ and the Democratic Republic of Congo, or as it is sometimes called even now, Kinsasha-Congo; ${ }^{102}$ and, finally, Ireland.

\footnotetext{
${ }^{98}$ The third British ex-colony, Australia, that had gained Dominion status before independence is not included in this category due to the wisdom of 1900 Constituents, even though it would belong to this category according to the linguistic practice of several countries, in which both its names are known, erroneously, as Australia, instead of Australia and Commonwealth of Australia. The Constitution Act adopted in 1900 and amended several times since, set forth that the various states of Australia "shall be united in a Federal Commonwealth under the name of the Commonwealth of Australia." See Australian Constitution s 3.

${ }^{99}$ The odd one out in this subgroup is Burkina Faso, which earlier was a French colony in West Africa.

${ }^{100}$ In connection with the name of this state, see Takács, supra note 25 , at $8-9$

${ }^{101}$ On the British list of country names and state titles, see COUNTRY NAMES, supra note 19. This country is named "Congo." The practice of German and Austrian authorities corresponds to this, whereby the country is called "Kongo"; however, the Swiss-German name is different from that, being "Kongo (Brazzaville)" on the basis of its capital.

${ }^{102}$ On the British list of country names and state titles, see COUNTRY NAMES, supra note 19. This country is included as Congo, Democratic Republic. The practice of German and Austrian authorities corresponds to this, whereby the country is called Kongo, Demokratische Republik. The Swiss-German name is, however, different; it is Kongo (Kinshasa) on the basis of its capital. LisTE DER STAATENNAMEN, supra note 20, at 8 (82).
} 
The state form of Ireland, or in Gaelic the Eire, is republic, despite the fact that Section 4 of the 1937 Constitution, which was approved by a referendum, does not refer to the state as a republic. (As known the 1937 Constitution repealed and replaced the 1922 Constitution, which named Eire the Irish Free State.) Accordingly, the name of the state is "Éire, or, in the English language, Ireland." It might be an interesting question whether Eire could or should be translated as Ireland, but due to lack of space, I cannot go into detail here. ${ }^{103}$ According to the 1948 Republic of Ireland Act, adopted by the Irish Oireachtas, which came into effect on Easter Monday in 1949, on the thirty-third anniversary of the so-called Easter Rising, "[i]t is hereby declared that the description of the State shall be the Republic of Ireland" (Section 2). ${ }^{104}$ The usage of the auxiliary verb structure "shall be," which is able to express and suggest multiple things in English depending on the context in which it is used, has historical and political reasons: Since the Easter Rising, many Irish people believe that only a state unifying the whole island of Ireland shall enjoy the name Irish Republic. ${ }^{105}$

The five states classified here are obviously joined by three permanently politically divided countries whose time of unification is generally not foreseeable under present circumstances. That being said, hope for the possibility of their unification in the future is not lost. Something that is not possible in the foreseeable future does not mean that it is entirely impossible. At least, the example of two German states and Germany illustrates that such hopes can, sooner or later, materialize or come true if they are grounded well in the ideals of a nation or organized people, and in that case, it will be reflected by the name of their state and country as well.

\section{F. Conclusion}

The main findings of this study are as follows. The current practice of denominating states by one of their two names was formed and accepted during the 20th century. This naming regime has been slowly developed in the context of more and more systematic, frequent, and ultimately stable international relations between states, drawing on previous experience. National name authorities and one of the expert groups of the United Nations played some role in the formation of this regime in the second half of that century, even though neither a unified constitutional practice has been formed in the legal systems nor have obligatory rules been developed in international law concerning naming states.

States cannot be named precisely until we clarify, arrange, and to some extent unify the terms currently used by different national terminological systems. It has been proven that in a clarified terminology, only one pair of terms can be used consistently: The country name and state name, or state title, adjusted if necessary with the help of the short-form and the long-form of state name; or vice-versa, the short and the long-form of state names interpreted according to country name and state name. Part of this finding is that state names cannot be treated as mere geographical names; they are so much more than geographical names, just as institutions are much more than units drawn on maps. It has been proven that the public law elements expressed in the names of states must take into consideration the name's regime. Without these elements, the concept of the state will be narrowed to that of the country, and the latter will be narrowed to a simple spot on the map. The study of names of states as institutions requires a complex approach of linguistics, geography, and theory of state that we can see as political science and jurisprudence. This study not only showed that state names can only be analyzed in an interdisciplinary way, but also that it leads to terminological and, behind that, conceptual confusion if one of the disciplines gets

\footnotetext{
${ }^{103}$ The debate in the House of Lords over the ratification of the Good Friday Agreement in 1998 provides interesting additions to the translation of Éire as Ireland. See 593 Parl Deb HL (1998) col. 1188 (UK).

${ }^{104}$ The Republic of Ireland Act 1948 (Act No. 22/1948) (Ir.).

${ }^{105}$ On the name of Ireland in historical context, see Mary E. Daly, The Irish Free State / Éire / Republic of Ireland / Ireland: A Country by Any Other Name?, 46 J. Brit. Stud. 72-90 (2007); Oran Doyle, The Constitution of Ireland: A ConTEXtual ANALYSIS (2018). In the historically wider context dating back to the Ancient times, see George Broderick, The Names for Britain and Ireland Revisited, 44 BEITRÄGE ZUR NAMENFORSCHUNG 151-72 (2009).
} 
disproportionately more emphasis than the others or one of them does not contribute sufficiently to the analysis.

In the actual naming practice of states there are three main ways of denomination states: (i) making a clear-cut difference between country name, short-form of state name, and state title, long-form of state name; (ii) naming countries by state name and naming states by country name; and (iii) accepting, maybe only temporarily, that politically divided countries are inevitable exceptions of the common naming regime. The solution that a state chooses between the first two depends in part on its traditions, but changing it says a lot about its actual policy too. This also proves that there are important political, legal, and cultural determinants behind the names of states, the way of naming them, and the related terminology used for their analysis. 